\title{
The Crystal and Molecular Structure of 8,2'-Cycloadenosine Trihydrate
}

\author{
By S. Neidle, ${ }^{*}$ G. L. Taylor and P. C. Cowling \\ Department of Biophysics, University of London, King's College, 26-29 Drury Lane, London WC2B 5RL, \\ England
}

(Received 24 October 1978; accepted 6 December 1978)

\begin{abstract}
$8,2^{\prime}$-Cycloadenosine, $\mathrm{C}_{10} \mathrm{H}_{11} \mathrm{~N}_{5} \mathrm{O}_{4} \cdot 3 \mathrm{H}_{2} \mathrm{O}$, is a modified arabinosyladenosine nucleoside which has been cyclized at the $\mathrm{C}(8)$ and $\mathrm{O}\left(2^{\prime}\right)$ atoms. THe trihydrate crystallizes in the orthorhombic space group $P 22_{1} 2_{1} 2_{1}$, with $a=8.680$ (2), $b=5.991$ (2), $c=27.203$ (4) $\AA, Z$ $=4$. The structure was refined to $R=0.0672$ for 1411 unique reflections, photographically recorded. The arabinofuranose ring has a flattened $\mathrm{C}\left(4^{\prime}\right)$-endo- $\mathrm{C}\left(3^{\prime}\right)$ exo pucker. The conformation about $\mathrm{C}\left(4^{\prime}\right)-\mathrm{C}\left(5^{\prime}\right)$ is gauche-gauche, and that about the sugar-base bond is high anti. The crystal structure involves extensive base-base hydrogen bonding, $\mathrm{N}(1), \mathrm{N}(6)$ and $\mathrm{N}(7)$ all being participants.
\end{abstract}

\section{Introduction}

Many arabinofuranosyl nucleosides act as antimetabolites, with potent antileukaemic and antiviral activity (Suhadolnik, 1970). Prominent among these is 9- $\beta$-Darabinofuranosyladenine (ara-A). It has been found that $8,2^{\prime}-O$-cyclo-9- $\beta$-D-arabinofuranosyladenine (Fig. 1) $\left(8,2^{\prime}\right.$-cycloadenosine), which is obtainable in relatively large quantities, can be converted into ara-A in quantitative yield (Chattopadhyaya \& Reese, 1977). The cyclonucleosides themselves possess biological activity, for example cyclo-ara-C is markedly active against leukaemic and other tumour cells (Hoshi, Kauzauna, Juretani, Saneyaski \& Arai, 1971). 8,2'Cycloadenosine is at present being screened for activity.

* To whom correspondence should be addressed.

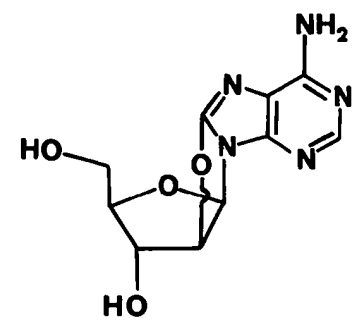

Fig. 1. 8,2'-Cycloadenosine.

0567-7408/79/030708-05\$01.00
The cyclonucleosides are also of interest in ORD and CD spectroscopic studies on nucleoside conformation, on account of the imposed restriction to rotational freedom about the glycosidic bond caused by the cyclization.

This study is the first to report the crystal structure of a purine cyclonucleoside, and continues our series on nucleoside and nucleotide conformation (Neidle, Kuhlbrandt \& Achari, 1976; Neidle, Taylor \& Robins, 1978; Neidle, Achari, Sheldrick, Reese \& Bridson, 1978).

\section{Experimental}

The title compound readily formed large, colourless, elongated prisms from aqueous solution. They were unstable in air, so were kept sealed in a thin-walled quartz capillary tube with mother liquor. Photographs revealed that the crystals were orthorhombic. Systematic absences $h 00: h=2 n+1 ; 0 k 0: k=2 n+1$; and $00 l: l=2 n+1$ uniquely identified the space group as $P 2,2,2$, Cell dimensions were obtained from twocircle diffractometer measurements.

\section{Crystal data}

$\mathrm{C}_{10} \mathrm{H}_{11} \mathrm{~N}_{5} \mathrm{O}_{4} \cdot 3 \mathrm{H}_{2} \mathrm{O}, M_{r}=319 \cdot 2$, orthorhombic prisms elongated along $\mathbf{b} ; a=8.680(2), b=5.991$ (2), $c=27.203$ (4) $\AA, V=1414 \AA^{3}, D_{m}=1.48$ (by flotation), $D_{c}=1.499 \mathrm{Mg} \mathrm{m}^{-3}$ for $Z=4, F(000)=$ 552, $\mu=0.76 \mathrm{~mm}^{-1}$ for $\mathrm{Cu} K_{\alpha}$ radiation $\left(\lambda_{\alpha}=\right.$ $1.54178 \AA$ ); space group $P 22_{1} 2_{1}$.

Intensities were collected photographically by the Weissenberg method with multi-film packs. The crystal was mounted about $\mathbf{b}$ and layers $h 0 l-h 5 l$ were collected with timed exposures. Intensities were evaluated by the SRC Microdensitometer Service with an Optronics film scanner. 1411 unique reflections were obtained after scaling and merging 2876 measured reflections. The merging agreement index, $R_{\mathrm{SYM}}$, was 0.0495 .

\section{Structure solution and refinement}

The structure was solved with MULTAN (Germain, Main \& Woolfson, 1971), employing magic integers (c) 1979 International Union of Crystallography 
(Main, 1978). It was refined by full-matrix least squares with anisotropic temperature factors for the nonhydrogen atoms. $\mathrm{H}$ atoms were not located in a difference synthesis; where possible their positions were calculated from geometric considerations, and their contributions taken into account during the refinement. To avoid singularities during the simultaneous refinement of interlayer scale factors and anisotropic $\left(U_{i j}\right)$ terms, $U_{33}$ was constrained to equal the mean of $U_{11}$ and $U_{22}$. The final $R$ was 0.0672 and $R_{w}$ was 0.0684 , with weights $w=1.0 /\left(F_{o}+0.0209 F_{o}^{2}\right)$. Tables 1 and 2 list the final atomic parameters.*

\section{Discussion}

\section{The molecular structure}

Bond lengths and angles are shown in Fig. 2. The e.s.d.'s in lengths range from 0.008 to $0.011 \AA$ and in

* Lists of structure factors and anisotropic thermal parameters have been deposited with the British Library Lending Division as Supplementary Publication No. SUP 34116 (9 pp.). Copies may be obtained through The Executive Secretary, International Union of Crystallography, 5 Abbey Square, Chester $\mathrm{CH} 12 \mathrm{HU}$, England.

Table 1. Final positional parameters for the nonhydrogen atoms $\left(\times 10^{4}\right)$, with e.s.d.'s in parentheses

$\begin{array}{lccc} & x & y & z \\ \mathrm{~N}(1) & 11638(7) & 5400(9) & 4682(2) \\ \mathrm{C}(2) & 11964(10) & 3550(13) & 4427(3) \\ \mathrm{N}(3) & 11042(7) & 2046(10) & 4215(2) \\ \mathrm{C}(4) & 9560(7) & 2654(12) & 4291(2) \\ \mathrm{C}(5) & 9007(8) & 4484(12) & 4542(2) \\ \mathrm{C}(6) & 10120(9) & 5925(11) & 4742(2) \\ \mathrm{N}(6) & 14762(7) & 7209(10) & 5005(2) \\ \mathrm{N}(7) & 7374(7) & 4757(10) & 4543(2) \\ \mathrm{C}(8) & 7058(8) & 2791(12) & 4301(2) \\ \mathrm{N}(9) & 8248(7) & 1527(8) & 4135(2) \\ \mathrm{C}\left(1^{\prime}\right) & 7757(7) & -364(12) & 3851(2) \\ \mathrm{O}\left(1^{\prime}\right) & 8021(6) & -185(8) & 3347(2) \\ \mathrm{C}\left(2^{\prime}\right) & 5982(8) & -225(12) & 3939(2) \\ \mathrm{O}\left(2^{\prime}\right) & 5683(6) & 1897(8) & 4187(2) \\ \mathrm{C}\left(3^{\prime}\right) & 5281(8) & -206(11) & 3425(2) \\ \mathrm{O}\left(3^{\prime}\right) & 4652(6) & -2378(8) & 3318(2) \\ \mathrm{C}\left(4^{\prime}\right) & 6624(8) & 313(11) & 3076(2) \\ \mathrm{C}\left(5^{\prime}\right) & 6678(12) & 2712(14) & 2887(3) \\ \mathrm{O}\left(5^{\prime}\right) & 6801(6) & 4282(8) & 3278(2) \\ \mathrm{O} W(1) & 1527(8) & 2011(11) & 2807(2) \\ \mathrm{O} W(2) & 9761(7) & -4499(10) & 3102(2) \\ \mathrm{O} W(3) & 11630(7) & -1395(10) & 3537(2)\end{array}$

Table 2. Calculated positional parameters $\left(\times 10^{3}\right)$ for the $\mathrm{H}$ atoms assigned a temperature factor of $0.04 \AA^{2}$

$\begin{array}{lrrr} & x & y & z \\ \mathrm{H}(\mathrm{C} 2) & 1318 & 319 & 439 \\ \mathrm{H}\left(\mathrm{C} 1^{\prime}\right) & 836 & -187 & 395 \\ \mathrm{H}\left(\mathrm{C} 2^{\prime}\right) & 553 & -158 & 416 \\ \mathrm{H}\left(\mathrm{C} 3^{\prime}\right) & 436 & 100 & 339 \\ \mathrm{H}\left(\mathrm{C} 4^{\prime}\right) & 649 & -69 & 275 \\ \mathrm{H}\left(\mathrm{C} 5^{\prime} 1\right) & 564 & 305 & 268 \\ \mathrm{H}\left(\mathrm{C} 5^{\prime} 2\right) & 766 & 289 & 265\end{array}$

angles from 0.3 to $0.7^{\circ}$. As shown in Fig. 3(a) and $(b)$ the formation of the ether linkage between the sugar and the base results in an essentially planar fused threering system. Table 3 shows that, of the atoms in the fourth ring, $\mathrm{C}\left(2^{\prime}\right)$ deviates the most from this plane, by only $0.131 \AA$.

Bond lengths for the base are almost identical with those in ara-A (Bunick \& Voet, 1974), as are the angles. The only exceptions are $C(5)-N(7)-C(8)$, which is about $4^{\circ}$ smaller, and $N(7)-C(8)-N(9)$, which is about $4^{\circ}$ larger than in ara-A. The formation of the $\mathrm{C}(8)$ $\mathrm{O}\left(2^{\prime}\right)$ ether linkage has created major changes in the

Table 3. Deviations ( $\AA$ ) of atoms from least-squares planes

\begin{tabular}{lrrrrr} 
& \multicolumn{2}{c}{ Adenine ring } & \multicolumn{2}{c}{ Furanose ring } \\
$\mathrm{N}(1)$ & 0.008 & $\mathrm{~N}(7)$ & -0.005 & $\mathrm{C}\left(1^{\prime}\right)$ & 0.000 \\
$\mathrm{C}(2)$ & -0.006 & $\mathrm{C}(8)$ & 0.003 & $\mathrm{O}\left(1^{\prime}\right)$ & 0.000 \\
$\mathrm{~N}(3)$ & -0.005 & $\mathrm{~N}(9)$ & 0.005 & $\mathrm{C}\left(2^{\prime}\right)$ & 0.000 \\
$\mathrm{C}(4)$ & -0.005 & ${ }^{*} \mathrm{C}\left(1^{\prime}\right)$ & -0.049 & ${ }^{*} \mathrm{C}\left(3^{\prime}\right)$ & -0.154 \\
$\mathrm{C}(5)$ & 0.003 & ${ }^{*} \mathrm{C}\left(2^{\prime}\right)$ & 0.131 & ${ }^{*} \mathrm{C}\left(4^{\prime}\right)$ & 0.149 \\
$\mathrm{C}(6)$ & -0.002 & ${ }^{*} \mathrm{O}\left(2^{\prime}\right)$ & 0.037 & ${ }^{*} \mathrm{C}\left(5^{\prime}\right)$ & 1.534 \\
$\mathrm{~N}(6)$ & -0.002 & & & &
\end{tabular}

* Atoms not included in the planes calculations.

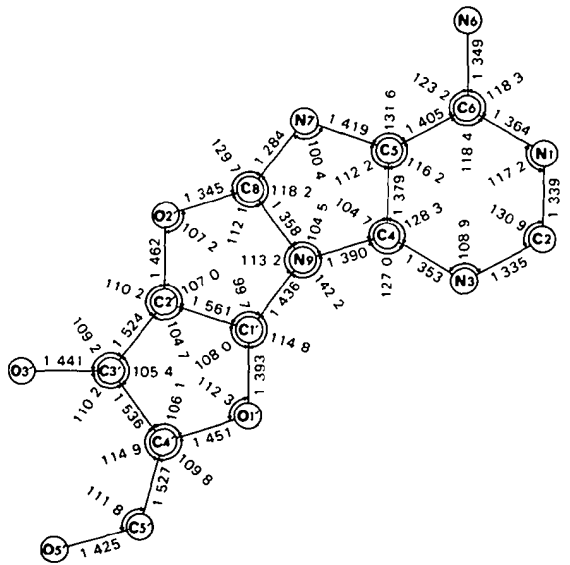

Fig. 2. Bond lengths $(\AA)$ and angles $\left(^{\circ}\right)$.

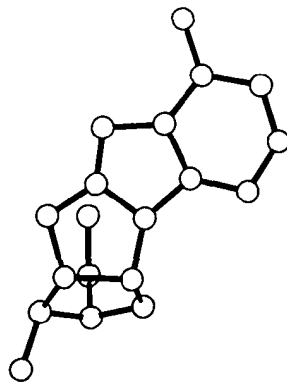

(a)

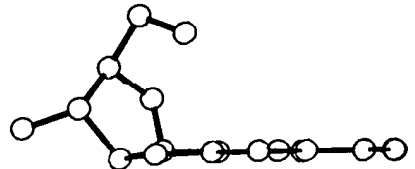

(b)
Fig. 3. Views of the cycloadenosine molecule $(a)$ perpendicular to and $(b)$ along the plane of the adenine base. 
angles around $\mathrm{N}(9), \mathrm{C}\left(1^{\prime}\right)$ and $\mathrm{C}\left(2^{\prime}\right)$ (Table 4). The only significant bond-length change is in $\mathrm{C}\left(2^{\prime}\right)-\mathrm{O}\left(2^{\prime}\right)$ which is $0.05 \AA$ longer in $8,2^{\prime}$-cycloadenosine than in ara-A. $\mathrm{O}\left(2^{\prime}\right)-\mathrm{C}(8), 1.345 \AA$, shows considerable double-bond character.

The angle between the plane of the fused three-ring system [including $\mathrm{C}\left(1^{\prime}\right), \mathrm{C}\left(2^{\prime}\right)$ and $\mathrm{O}\left(2^{\prime}\right)$ ] and the ribose ring is $115^{\circ}$; the corresponding angle in cyclocytidine (Brennan \& Sundaralingam, 1973) is $109^{\circ}$.

The glycosidic torsion angle $\chi$ (Table 5) is $107^{\circ}$, corresponding to a high anti conformation. Thus, the $8,2^{\prime}$-cyclization has restricted this angle to a much larger value than in either adenosine itself (Lai \& Marsh, 1972) $\left(10^{\circ}\right)$ or ara-A (Bunick \& Voet, 1974) $\left(58^{\circ}\right)$. Table 5 compares the major torsion angles with those found for related compounds.

The sugar pucker in 8,2'-cycloadenosine can be described as $C\left(4^{\prime}\right)$-endo-C $\left(3^{\prime}\right)$-exo (Table 3 ). This, or simple variants, appears to be the dominant conformation in the cyclonucleoside series and has also been observed in 2',3'-O-isopropylideneadenosine (Sprang, Rohrer \& Sundaralingam, 1978). The sugar ring is almost flat, contrasting with the more pronounced

Table 4. A comparison of some bond angles $\left(^{\circ}\right)$ in $8,2^{\prime}$-cycloadenosine with those in ara-A (Bunick \& Voet, 1974)

$\begin{array}{lcc} & \text { This study } & \text { Ara-A } \\ \mathrm{C}(8)-\mathrm{N}(9)-\mathrm{C}\left(1^{\prime}\right) & 113.2 & 127 \cdot 1 \\ \mathrm{C}(4)-\mathrm{N}(9)-\mathrm{C}\left(1^{\prime}\right) & 142.2 & 126.0 \\ \mathrm{~N}(9)-\mathrm{C}\left(1^{\prime}\right)-\mathrm{C}\left(2^{\prime}\right) & 99.7 & 114.9 \\ \mathrm{C}\left(1^{\prime}\right)-\mathrm{C}\left(2^{\prime}\right)-\mathrm{O}\left(2^{\prime}\right) & 107.0 & 114.7 \\ \mathrm{~N}(9)-\mathrm{C}\left(1^{\prime}\right)-\mathrm{O}\left(1^{\prime}\right) & 114.8 & 107.3\end{array}$

buckle of non-cyclonucleosides, where an out-of-plane atom commonly deviates by over $0.5 \AA$ from the best plane of the other four. This is also reflected in the maximum amplitude of pucker $\left(\tau_{m}\right)$ which is only $18.9^{\circ}$, compared with an average of $39^{\circ}$ for normal arabinose and ribose rings (Altona \& Sundaralingam, 1972). However, Table 4 shows that the value of $\tau_{m}$ for $8,2^{\prime}$-cycloadenosine is low even for cyclonucleosides.

The $\mathrm{C}\left(4^{\prime}\right)$-endo conformational restriction of the cyclonucleosides is a result of the inhibition of rotational freedom about $\mathrm{C}\left(1^{\prime}\right)-\mathrm{C}\left(2^{\prime}\right)\left(\tau_{1}\right)$ caused by cyclization. As a result, $C\left(4^{\prime}\right)$ is the most mobile atom of the ring. Recent quantum-mechanical calculations (Levitt \& Warshal, 1978) on the conformational flexibility of the furanose ring in DNA and RNA have shown that if $\tau_{3}$ is constrained to follow a pseudorotational pathway and all other variables (i.e. atomic coordinates) are allowed to relax during energy minimization, then for values of the pseudorotation angle $P$ between 240 and $300^{\circ}$ [i.e. inclusive of the $\mathrm{C}\left(4^{\prime}\right)$-endo conformer], the sugar ring becomes more planar. The results also show that this more planar $\mathrm{C}\left(4^{\prime}\right)$-endo sugar conformation is not energetically less favoured than a conventional $\mathrm{C}\left(4^{\prime}\right)$-endo conformation with a maximum pucker $\left(\tau_{m}\right)$ of around $40^{\circ}$.

The conformation about the exocyclic bond of the arabinose ring is almost perfectly gauche-gauche despite the fact that this results in close contacts between $\mathrm{O}\left(5^{\prime}\right)$ and the base $\mathrm{C}(8)$ of $2.93 \AA$, and between $O\left(5^{\prime}\right)$ and $O\left(1^{\prime}\right)$ of $2.88 \AA$.

\section{The crystal structure}

Fig. 4 shows the hydrogen bonding involving the adenine bases. Each one links to two others, producing

Table 5. Major torsion angles $\left(^{\circ}\right)$ for the cyclonucleosides

\begin{tabular}{|c|c|c|c|c|c|c|c|c|c|}
\hline \multirow{2}{*}{ Glycosidic angle } & $\begin{array}{l}\text { This } \\
\text { study }\end{array}$ & $\begin{array}{l}\text { Ara-A } \\
(a)\end{array}$ & $\begin{array}{c}\text { Ara-A } \\
\mathrm{HCl}(b)\end{array}$ & \multicolumn{2}{|c|}{ Cyclo-U (c) } & $\begin{array}{l}\text { Cyclo-C } \\
\text { (d) }\end{array}$ & \multicolumn{2}{|c|}{ Cyclopyridone } & $\begin{array}{c}\text { Range of } \tau_{j} \\
\text { values in } \\
\text { cyclonucleosides }\end{array}$ \\
\hline & & & & & & & & & \\
\hline$C(8)-N(9)-C\left(1^{\prime}\right)-O\left(1^{\prime}\right)$ & $107 \cdot 0$ & $57 \cdot 8$ & 29.7 & $-65 \cdot 5$ & $-70 \cdot 0$ & $-61 \cdot 4$ & $-67 \cdot 4$ & $-68 \cdot 0$ & \\
\hline 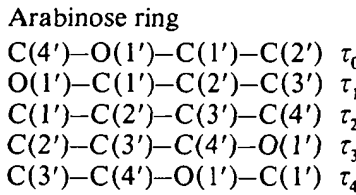 & $\begin{array}{r}6.4 \\
6.0 \\
-15 \cdot 0 \\
18.9 \\
-16 \cdot 1\end{array}$ & $\begin{array}{r}-4 \cdot 4 \\
-19 \cdot 0 \\
33.5 \\
-36.9 \\
26.2\end{array}$ & $\begin{array}{r}6.4 \\
-28 \cdot 7 \\
39 \cdot 1 \\
-36 \cdot 0 \\
18 \cdot 8\end{array}$ & $\begin{array}{r}14 \cdot 4 \\
4 \cdot 2 \\
-19 \cdot 7 \\
28 \cdot 3 \\
-27 \cdot 3\end{array}$ & $\begin{array}{r}9 \cdot 3 \\
12 \cdot 9 \\
-28 \cdot 6 \\
34 \cdot 5 \\
-27 \cdot 7\end{array}$ & $\begin{array}{l}- \\
- \\
- \\
-\end{array}$ & $\begin{array}{r}31 \cdot 2 \\
-8 \cdot 9 \\
-14 \cdot 6 \\
33 \cdot 5 \\
-41 \cdot 0\end{array}$ & $\begin{array}{r}-14 \cdot 5 \\
-2 \cdot 9 \\
17 \cdot 5 \\
-26 \cdot 4 \\
25 \cdot 6\end{array}$ & $\begin{array}{l}45 \cdot 7 \\
21 \cdot 8 \\
46 \cdot 1 \\
60 \cdot 9 \\
66 \cdot 6\end{array}$ \\
\hline Pseudorotation angle & $217 \cdot 5$ & $25 \cdot 2$ & $9 \cdot 3$ & $227 \cdot 3$ & $213 \cdot 6$ & 233 & $248 \cdot 6$ & $49 \cdot 7$ & \\
\hline $\begin{array}{l}\text { Maximum pucker } \\
\text { Exocyclic angles }\end{array}$ & $\begin{array}{c}18 \cdot 9 \\
{ }^{4} T_{3}\end{array}$ & $\begin{array}{c}37 \cdot 0 \\
{ }^{3} T_{4}\end{array}$ & $\begin{array}{l}40 \cdot 2 \\
{ }^{3} T_{2}\end{array}$ & $\begin{array}{l}29 \cdot 0 \\
{ }^{4} T_{3}\end{array}$ & $\begin{array}{c}34 \cdot 4 \\
{ }_{3}^{4} T\end{array}$ & ${ }^{-}$ & $\begin{array}{l}40 \cdot 0 \\
{ }^{4} T_{0}\end{array}$ & $\begin{array}{r}27 \cdot 1 \\
{ }_{4} T^{5}\end{array}$ & \\
\hline $\begin{array}{l}O\left(5^{\prime}\right)-C\left(5^{\prime}\right)-C\left(4^{\prime}\right)-O\left(1^{\prime}\right) \\
O\left(5^{\prime}\right)-C\left(5^{\prime}\right)-C\left(4^{\prime}\right)-C\left(3^{\prime}\right)\end{array}$ & $\begin{array}{r}-60 \cdot 2 \\
59 \cdot 3\end{array}$ & $\begin{array}{r}62 \cdot 1 \\
178 \cdot 8\end{array}$ & $\begin{array}{r}-62 \cdot 3 \\
55 \cdot 1\end{array}$ & $\begin{array}{r}56 \cdot 0 \\
174 \cdot 7\end{array}$ & $\begin{array}{r}54 \cdot 8 \\
173 \cdot 5\end{array}$ & $\begin{array}{r}-69 \cdot 8 \\
51 \cdot 0\end{array}$ & $\begin{array}{r}69 \cdot 5 \\
174 \cdot 2\end{array}$ & $\begin{array}{c}169.9 \\
71.8\end{array}$ & \\
\hline & $g g$ & $g t$ & $g g$ & $g t$ & $g t$ & $g t$ & $g t$ & $\operatorname{tg}$ & \\
\hline
\end{tabular}

References: (a) Bunick \& Voet (1974). (b) Chwang, Sundaralingam \& Hanessian (1974). (c) Delbaere \& James (1973); Suck \& Saenger (1973). (d) Brennan \& Sundaralingam (1973). (e) Hutcheon \& James (1977). 


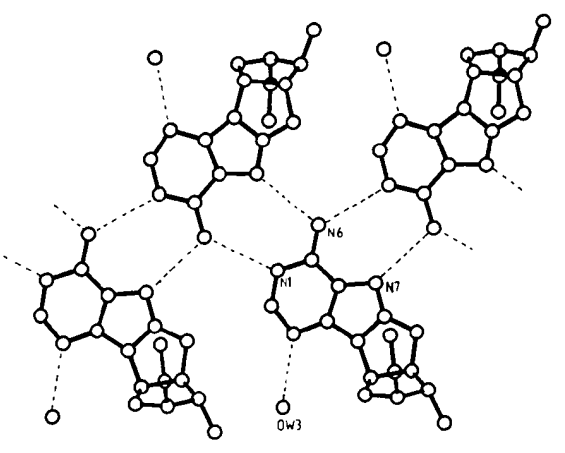

Fig. 4. The hydrogen bonding of the bases.

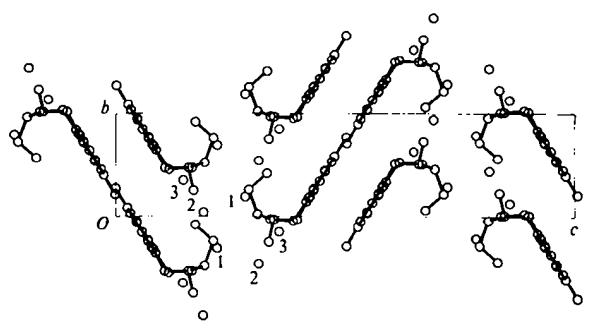

Fig. 5. Projection down a of the crystal structure; several water molecules are numbered.

Table 6. Hydrogen-bond distances (average e.s.d. $0.010 \AA)$

$\begin{array}{lll}\text { Atom 1 } & \text { Atom 2 } & \\ \mathrm{N}(6) & \mathrm{N}(1) & 3.050 \AA \\ \mathrm{N}(6) & \mathrm{N}(7) & 3.034 \\ \mathrm{~N}(3) & \mathrm{O} W(3) & 2 \cdot 814 \\ \mathrm{O}\left(3^{\prime}\right) & \mathrm{O} W(3) & 2 \cdot 754 \\ \mathrm{O}\left(3^{\prime}\right) & \mathrm{O}\left(5^{\prime}\right) & 2 \cdot 737 \\ \mathrm{O}\left(5^{\prime}\right) & \mathrm{O} W(2) & 2 \cdot 713 \\ \mathrm{O} W(1) & \mathrm{O} W(2) & 2 \cdot 714 \\ \mathrm{O} W(1) & \mathrm{O} W(2) & 2 \cdot 860 \\ \mathrm{O} W(1) & \mathrm{O} W(3) & 2 \cdot 848 \\ \mathrm{O} W(2) & \mathrm{O} W(3) & 2 \cdot 736\end{array}$

Symmetry operation on atom 2

an infinite chain of base pairs. The adenine group utilizes not only $\mathrm{N}(1)$ and $\mathrm{N}(6)$ as donor and acceptor (Table 6) (as found in Watson-Crick adenine-thymine base pairs) but also $N(6)$ and $N(7)$, as in Hoosteen-like base-pairing. Identical mixed base-pairing arrangements have been frequently observed, for example in deoxyadenosine (Watson, Sutor \& Tollin, 1965), 9methyladenine (Stewart \& Jensen, 1964) and 2'-Omethyladenosine (Prusiner \& Sundaralingam, 1976), and appears to be an important mode of interaction between neutral adenine bases. The geometry found here accords well with that noted in these other structures. There is no twist between the planes of the interacting bases; the crystallogrpahic symmetry necessitates this coplanarity (Fig. 5).

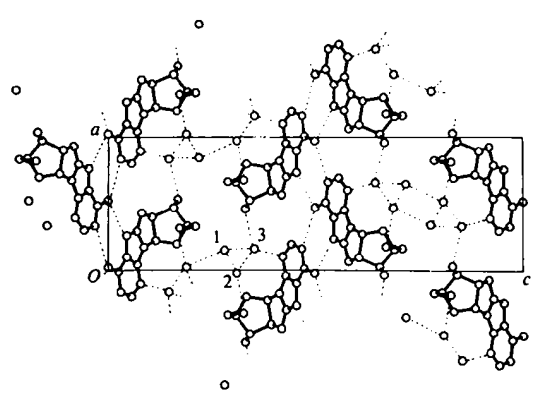

Fig. 6. Projection down $b$ of the crystal structure.

Fig. 6 shows the projection down b of the crystal structure, revealing the extensive network of hydrogen bonds between waters, bases and $O\left(2^{\prime}\right)$ and $O\left(3^{\prime}\right)$ of the arabinose group. All the hydrogen-bond interactions are summarized in Table 6. The base-pair hydrogen bonds link molecules along $\mathrm{c}$.

All the water molecules participate in their maximum number of hydrogen bonds. However, owing to our inability to locate $\mathrm{H}$ atoms, an unequivocal assignment of most of the donors and acceptors involving the water molecules cannot be performed.

We thank the Cancer Research Campaign for support, the Science Research Council for a studentship (to GLT), Dr J. B. Chattopadhyaya and Professor C. B. Reese for the provision of crystals, and the SRC Microdensitometer Service for facilities.

\section{References}

Altona, C. \& Sundaralingam, M. (1972). J. Am. Chem. Soc. 94, 8205-8212.

Brennan, T. \& Sundaralingam, M. (1973). Biochem. Biophys. Res. Commun. 52, 1348-1353.

Bunick, G. \& Voet, D. (1974). Acta Cryst. B30, 16511660.

Chattopadhyaya, J. B. \& Reese, C. B. (1977). J. Chem. Soc. Chem. Commun. pp. 414-415.

Chwang, A. K., Sundaralingam, M. \& Hanessian, S. (1974). Acta Cryst. B30, 2273-2277.

Delbaere, L. T. J. \& James, N. M. G. (1973). Acta Cryst. B29, 2905-2912.

Germain, G., Main, P. \& Woolfson, M. M. (1971). Acta Cryst. A27, 368-376.

Hoshi, A., Kauzauna, F., Juretani, K., Saneyaski, M. \& ARAI, Y. (1971). Gann, pp. 145-146.

Hutcheon, W. L. B. \& James, N. M. G. (1977). Acta Cryst. B33, 2228-2232.

LAI, T. F. \& MARsH, R. E. (1972). Acta Cryst. B28, 19821989.

Levitt, M. \& Warshal, A. (1978). J. Am. Chem. Soc. 94, 2607-2613.

MaIn, P. (1978). Acta Cryst. A34, 31-38.

Neidle, S., Achari, A., Sheldrick, G. M., Reese, C. B. \& Bridson, P. K. (1978). Acta Cryst. B34, 2794-2798. 
Neidle, S., Kuhlbrandt, W. \& Achari, A. (1976). Acta Cryst. B32, 1850-1855.

Neidle, S., Taylor, G. L. \& Robins, A. B. (1978). Acta Cryst. B34, 1838-1841.

Prusiner, P. \& Sundaralingam, M. (1976). Acta Cryst. B32, 161-169.

Sprang, S., Rohrer, D. C. \& Sundaralingam, M. (1978). Acta Cryst. B34, 2803-2810.
Stewart, R. F. \& Jensen, L. H. (1964). J. Chem. Phys. 40, 2071-2075.

Suck, D. \& Saenger, W. (1973). Acta Cryst. B29, 13231330.

SuHADOLNIK, R.-J. (1970). Nucleoside Antibiotics. New York: Interscience.

Watson, D. G., Sutor, D. J. \& Tollin, P. (1965). Acta Cryst. 19, 111-124.

Acta Cryst. (1979). B35, 712-716

\title{
The Structures of 4-Methoxy-2,6-dimethylbenzonitrile $\mathrm{N}$-Oxide (I), 4-Bromo- 2,6-dimethylbenzonitrile $N$-Oxide (II) and 2,4,6-Trimethylbenzonitrile $N$-Oxide (III)
}

\author{
By Motoo Shiro, Masumi Yamakawa and Tanekazu Kubota \\ Shionogi Research Laboratory, Shionogi \& Co. Ltd, Fukushima-ku, Osaka 553, Japan
}

(Received 27 September 1978; accepted 6 December 1978)

\begin{abstract}
The crystal structures of (I), (II) and (III) have been determined at $130 \mathrm{~K}$ (I) and $295 \mathrm{~K}$ (II, III). (I) is monoclinic, space group $P 2, / c, a=8.36(1), b=$ $12.76(2), c=9.01$ (1) $\AA$, $\beta=110.6(5)^{\circ}, Z=4$. (II) is monoclinic, space group $P 2_{1} / c, a=8.942(1), b=$ $7.040(1), c=16.966$ (2) $\AA, \beta=121 \cdot 16(1)^{\circ}, Z=4$. (III) is monoclinic, space group $C 2 / c, a=8.771$ (1), $b$ $=15.124$ (3), $c=7.070$ (1) $\AA, \beta=105.25(1)^{\circ}, Z=4$. The structures were refined by the least-squares method to $R$ indices of 0.071 (862 reflexions) for (I), 0.076 (974) for (II), and 0.163 (383) for (III). The details of the molecular structure of (III) were not obtained because of the disordered structure. The $\mathrm{N}-\mathrm{O}$ dative bond lengths are 1.249 (7) and 1.237 (10) $\AA$ in (I) and (II), respectively, which are shorter than those in trimethylamine $N$-oxide $(1.388 \AA)$ and pyridine $N$ oxide derivatives (in the range of $1.28-1.30 \AA$ ). The bond $-\mathrm{C} \equiv \mathrm{N} \rightarrow \mathrm{O}$ is considered to be linear, like those of fulminic acid and acetonitrile $N$-oxide. The hydrogen bonds between the $\mathrm{O}$ atom of the $N$-oxide group and the $\mathrm{C}$ atom in the benzene ring are weak compared with those found in crystals of pyridine $\mathrm{N}$-oxide derivatives.
\end{abstract}

\section{Introduction}

Various physico-chemical studies of substituted benzonitrile $N$-oxides (Kubota, Yamakawa, Takasuka, Iwatani, Akazawa \& Tanaka, 1967; Yamakawa, Kubota \& Akazawa, 1967; Yamakawa, Kubota, Akazawa \& Tanaka, 1968; Bastide, Maier \& Kubota,

0567-7408/79/030712-05\$01.00
1976) have revealed that the $-\mathrm{C} \equiv \mathrm{N} \rightarrow \mathrm{O}$ groups in benzonitrile $N$-oxides have the character of a partial triple bond, consisting of $\pi$ and $\bar{\pi}$ systems (Fig. 1), and that the $\mathrm{N}-\mathrm{O}$ dative bond lengths are, hence, shorter than those in aliphatic and aromatic amine $N$-oxides.

The structures of trimethylamine $N$-oxide (Caron, Palenik, Goldish \& Donohue, 1964) and pyridine $N$ oxide derivatives were investigated, but no structures of benzonitrile $\mathrm{N}$-oxides have been reported. The structure analyses of the three compounds were undertaken to confirm the electronic structure of benzonitrile $N$-oxide from a structural standpoint. The structure of (I) has been reported in a preliminary form by Shiro, Yamakawa \& Kubota (1968).

\section{Experimental}

Crystals of each compound were obtained from a methanol solution. Crystal data are given in Table 1.

Three-dimensional intensity data for (I) were collected at $130 \mathrm{~K}$ on integral Weissenberg photographs with Ni-filtered $\mathrm{Cu} K a$ radiation $(h 0 l-h 6 l$ and $0 k l-3 k l)$. Intensities were measured on a densitometer and those in the upper layer were corrected for spot size. Intensity

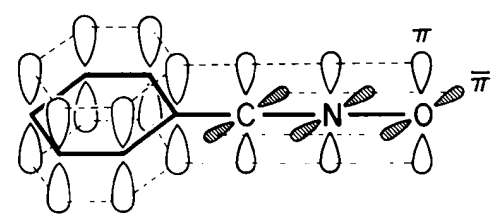

Fig. 1. Schematic $\pi$-resonance systems of benzonitrile $N$-oxide. (C) 1979 International Union of Crystallography 